\title{
The Construction of City Images in Micro Films: A Case Study
}

\section{of Taipei City Government}

\author{
Chia-ju, Lin ${ }^{1 *}$ \\ ${ }^{1}$ Journalism \& Mass Communication Program, International College, Ming Chuan University, Taipei, \\ Taiwan \\ *Chia-ju, Lin, E-mail: 11977126@yahoo.com.tw
}

\begin{abstract}
In recent years, with the rapid development of the media, an increasing number of corporations and even government agencies are using the new format known as the micro film as a means of advertising and marketing. In this study, we took the micro films produced by the Taipei City Government as objects of analysis to investigate the image of the city as constructed in and produced by these films. Furthermore, in this study, the symbol of image in three such micro films was studied: Love@Taipei, My Micro Tour of Taipei, and Happily Ever After. It was found that in these films, the characteristics of the city of Taipei have been presented accurately and successfully by means of the [appropriate selection of] celebrity performers, the romance narratives used, and the lively presentation of these films. Therefore, these films have foregrounded an image of Taipei that is free, friendly, diverse, and progressive; furthermore, they have successfully conveyed the idea that "Taipei is a city that is positive and capable of outstanding achievements". These films, designed to attract audiences, have been made with great skill and portray little elements of the government-run campaigns they are actually part of, thus making them even more entertaining for viewers.
\end{abstract}

\section{Keywords}

city marketing, city image, micro film

\section{Motivation and Objectives of the Study}

The widespread popularity and use of mobile equipment means that users can now enjoy music and video clips anytime, anywhere. The "micro film" format is a new format that has emerged due to this development. Currently, this method is popular not only with corporations but also with government agencies, with the micro film format used for the communication of issues of public interest and policies and even for city marketing. The new marketing model that is "city + micro film” works by drawing the audience in by laying out an attractive atmosphere in the film and with plot and narrative development. As the audience is drawn into the narrative, they also develop a stronger impression of the city and hence tend to favor the city. This is how the objective of city marketing is achieved (Yahoo! Kimo, 2012). 
The trend of micro films has substantially attracted the locales of Chinese majority, such as Taiwan, Hong Kong, and Singapore. Presently, the micro film can be described using several distinctive characteristics regarding technique, market, and cultural terms. Therefore, in this study, we took the micro films produced by the Taipei City Government as objects of analysis to investigate the city image as constructed and generated in these films.

\section{Literature Review}

Below is the description of the literature and theories relevant to this study.

\subsection{City Image and City Marketing}

In the concept of image, Bounding (1956) proposed that the image is the cognition of and attitude toward an object in the mind of the subject. Additionally, the image is an overall judgment that is subjective in nature. Human behavior is not only impacted by knowledge and information but also by the image that is formed in individuals' minds. Thereafter, Scott moved one step beyond to propose that the image is an organized representation of an object in the individual's cognitive system (Scott, 1965), a representation that consists of both cognition and emotion as well as an implication of the individual's memories, expectations, knowledge, and opinions of the object (Liu, 2001). The creation of the image can be said to be a dynamic and mobile process wherein the subject continually revises his or her cognition of the object due to the influence of external information and then makes a final judgment and evaluation based on the results of this process.

The term "city image", an extension of the concept of image, refers to the overall subjective opinion and viewpoint of a city on the part of individuals (Foot, 1999). City image is formed through memories as the individual observes, contacts, and gets to know the city better, with such memories then constituting significance for the individual. To reveal the levels that constitute city image, we can start from the city image differentiation hierarchy diagram (Lü, 2002) in Figure 1 below. Here, the image of a city can be observed from three levels from top to bottom: the overall values of the city, including the spirit and beliefs, reasons for existence, developmental goals and lifestyles of the city's denizens. Value differentiation can be regarded as the driving force of a city's differentiation method and part of a city's ultimate positioning. On the second level, we have differentiation of city behavior. This refers to the characteristics of the city's denizens and the related customs and habits practiced by local people. These characteristics and practices tend to adopt a regional color or flavor that is distinct to the city, such as in the case of the image of Paris as the city of romance. On the third level, we have visual differentiation of the city. This includes the landscape and cultural icons of the city, otherwise also known as environmental facilities or public systems. An example of such an icon would be the TAIPEI 101. In other words, city image is not a simple or one-dimensional view of the city. It is a comprehensive and complete impression of what a city is like, created by both the brain's processing of the individual's perception of various parts of the city and its material elements using their various sensory abilities as well as the individual's past experiences and knowledge of the city (Chang, 2006). 


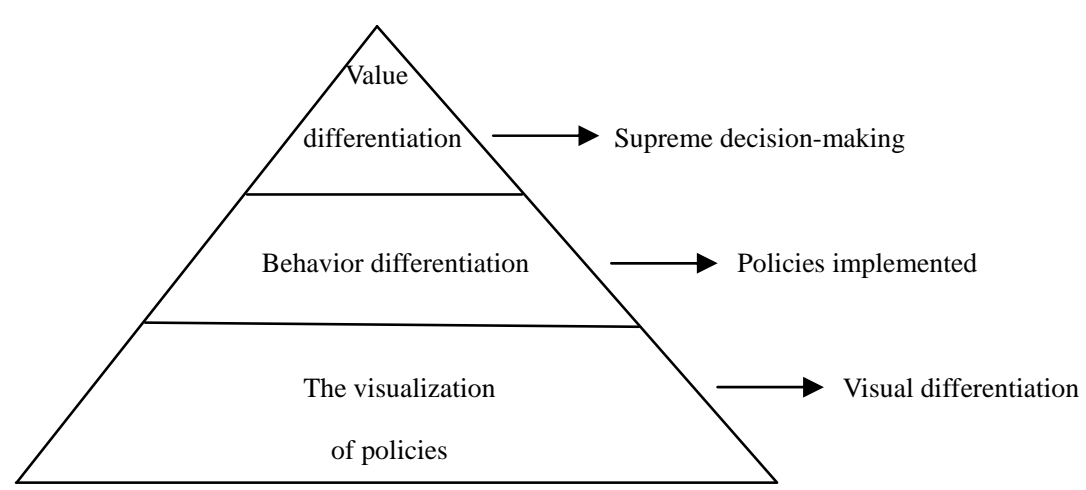

Figure 1. City Image Differentiation Hierarchy Diagram

How a city conveys its distinctive positioning in a positive manner can be said to be one of the most critical issues that cities face today, as the shaping of a positive city image can not only enhance the reputation of the city but also increase the city value. This is why municipal governments have been keen on using the concept of city image in their efforts to market their respective cities. With the concept of city marketing, the government moves from a guiding role to an active role amidst changing external conditions to ensure the sustainable development of the city by introducing marketing concepts into local development and emphasizing local competitiveness (Lee, 2011). Here, the practice of city marketing should be differentiated from product marketing that occurs in business: the "product” being promoted by the former is not an actual product, which is why a clear definition is not possible. Compared with the practice of product marketing, city marketing is non-profit oriented in nature and maintains close ties with social and public benefit as well as social responsibility (Ashworth \& Voogd, 1990). In addition, the city consists of various high-cost local construction and policies, making the practice of city marketing even more complex when compared with product marketing.

The practice of city marketing can be divided into two levels: the first level constitutes what is being marketed is an actual city "product" with an emphasis on the external form of the city. Here, the shaping of the physical environment by means of developing infrastructure and designing spatial layouts can help create an attractive urban landscape. The second level is the marketing of a more abstract product, with an emphasis on the "inherent nature" [of the city], as well as considering the image and brand of the city established through creation, communication, and management of customers' thought associations and feelings (Lin, 2009).

On the subject of city image, Graham (2002) has stated that the subject of city marketing is actually not the city per se but the idea or image of the city, which comprises the information that has been conveyed and successfully received by the recipient. According to Graham, there are actually two "cities" that co-exist in the idea of the "city": one is the "external city", that is, the distinguishing marks of the city, such as its buildings or landmarks. The second city is the "internal city", that is, the city of [the] mind, which consists of the information received by the individual as a result of specific experiences, feelings, and thought associations. Such information, which is then amalgamated, includes 
information on various lifestyles and cultural patterns. Hence, "city image” constitutes what is mutually complementary, the internal city, and the external city.

Regarding the numerous targets of city marketing as well as the stakeholders of such an exercise, Kavaratzis (2004) has proposed three modes of transmission:

The first, related to the actions of the municipal government and its policies, includes the following elements: landscape strategies such as urban design, architecture, and public art; infrastructure projects such as building cultural centers and convention centers; and organizational and administrative structure, i.e., measures designed to enhance the effectiveness of the municipal management structure, such as the establishment of private-public partnerships and the implementation of city marketing. Additionally, this mode includes behavior mode, which refers to the vision for the city as envisioned by municipal leaders and the strategies used regarding different stakeholders (Lin, 2009). Although the communication effect of these elements is related to municipal actions, such an effect may not be the main objective of such action.

The second mode comprises formal and targeted attempts at widespread communication through advertising, public relations, and design, along the lines similar to the 4Ps model (Product, Price, Place, and Promotion) used in product marketing (Kotler, 2002).

The third mode of communication is via reputation or word-of-mouth. This type of communication, typically, cannot be controlled, although it can be reinforced through the media or competitors' communication activities. This mode of communication can be seen as the objective of the preceding two modes. In particular, the denizens of the city can be said to be its most important marketers (Lee, 2011).

Local governments have used a plethora of media channels and formats to conduct city marketing, including print media, electronic media, international communication (such as through the naming of sister cities to promote tourism) and city communication (such as the communication conducted along with local festival activities). Micro film making, a relatively new development, involves revealing the "inner substance" of the city by using a narrative, with the narrative also designed to market the city's distinctive characteristics and charms in what is a display of what the city has to offer in terms of landscape and culture. For instance, The Story of Heart City (Xinchengshi Gushi), a micro film released by the New Taipei City government in 2013, showcased the metropolitan form after upgrading as well as several policy outcomes for the public.

\subsection{Micro Film Advertising}

Viewing video clips and films online has become commonplace because of the wide availability of mobile devices. Now, viewers can enjoy audiovisual content on their mobile devices regardless of time and space. This phenomenon has in turn created vast potential for the development of video and audio content online. Survey data from the Institute for Information Industry (Taiwan) shows that over $50 \%$ of (Taiwanese) consumers access mobile video and audio resources when commuting. This shows that the use of mobile devices for viewing video and audio content has become an accepted mode of 
entertainment for the majority of consumers (Chen, 2012).

The term "micro film" or wei dianying was first used in 2010 by the mainland Chinese media to describe a long advertisement titled Imminent (Yi Chu Ji Fa) (Chen, 2012). The widespread impact and popularity of the micro film then led more advertisers to enter into production of the format. However, before the emergence of the "micro film", short films made especially for a growing Internet audience had already appeared on the scene. Certainly, the refinement level and production standards of these short films fall short of those of the micro films today. However, indeed, the primordial concept and connotation of the micro film have existed prior to the coining of the term. Although this type of commercial films was not addressed by the name of "micro film", it displayed the features of a micro film. Characteristics of this type of films include "micro [in terms of] duration" (typically lasting between 30 seconds and 10 minutes), "micro production” (usually taking just days or weeks to shoot), and "micro [in] scale" (with production costs ranging from NTD 10,000 to NTD 1,000,000).

In general, micro films created thus far can be divided into two broad categories: the first is the custom micro film, which is made according to the order of either a corporate or official party. While both are produced for promotional purposes, the former is produced for the purposes of advertising a product, while the latter is typically produced not to advertise a specific product but with a focus on city image or the promotion of tourism in the city. Another type of micro film is the original [fictional] narrative film. There is a certain entry threshold to the shooting of this type of micro film in the sense that typically production personnel with professional audiovisual production skills are required for its production such that the final product is closer to what is shown in the "cinema" in terms of its artistic core. (Chen, 2014) The greatest difference between traditional advertising and micro film advertising is that the primary content of the micro film is a story that is more autonomous and unitary in nature (Hwang, 2013).

Currently, besides corporate entities, government agencies have also jumped onto the micro film bandwagon. These entities use the new integrated "city $\times$ micro film” model to enhance viewers' opinion of the city; thus, the objective of city marketing is achieved as viewers are drawn into the narrative with the help of [the appropriate] ambiance, plot developments, and performances. For example, in the wake of the March 2011 Tohoku earthquake and Fukushima nuclear disaster [in 2012], the Japan Tourism Agency partnered Yahoo! to produce a micro film titled Japan, Good for You (Riben, Zhen You Ni De). The film, which became a hit online, was successful in conveying the image of Japan that had successfully made a post-disaster recovery and where tourists could feel safe during their travels. This is an example of successful city marketing. 


\section{Study Method}

In this study, we deconstructed the symbol of city images used in the micro films by using the image-text analysis method. Like a language, video or film imagery generally contains meaning, both explicit and implicit. By the time film content appears in front of the viewer, the information within has already been "coded" to portray certain meanings. As such, the act of image-text analysis allows us to better understand the basic concepts constituted by the system network with the implicit and explicit systems of expression of films. Hence, the film analysis is not just about mere film appreciation or the study of film phenomena but even more related to the [study of the] symbolization (Wu, 2007).

For the image-text analysis undertaken in the study, we analyzed the plot, characters, dialogs, and landscape and scenery [in the three micro films] based on the space landscapes, cultural connotation, and lifestyles depicted in these films. The analytic definitions used (Lee, 2011) are as follows:

1) Plot: how the film narrative develops in relation to the city image.

2) Characters: the personalities of the film leads and supporting roles, as well as how they interact with each other.

3) Dialogs: the dialogs or voice-overs spoken by film characters, when read as descriptions of the city background.

4) Landscape and scenery: the visual presentation of the urban landscape in these films.

Since 2011, the micro film produced to promote the city image has risen in popularity, with several municipal governments working to produce and release such films. The Taipei city government is no exception to this trend. The three micro films that will be analyzed using the image-text analysis method in this study are Love@Taipei (Ai Shang Taibei), My Micro Tour of Taipei (Taibei, Wo De Wei Luxing), and Happily Ever After (Xingfu Zhuibuzhui). The objective of this study is to gain a better understanding of how government agencies use the micro film format to present an [preferred] image of Taipei city.

Among the three micro films examined, Love@Taipei and My Micro Tour of Taipei are multi-episode productions with each episode of two to four minutes. On the other hand, Happily Ever After is a single-episode production lasting nearly nine minutes. Details on the three micro films under study are as follows:

Table 1. Three Micro Films under Study

\begin{tabular}{llll}
\hline & Love@Taipei & My Micro Tour of Taipei & Happily Ever After \\
\hline Year released & 2012 & 2012 & 2013 \\
Duration & Five episodes of four & Fifteen episodes of two & Nine minutes \\
& minutes each & minutes each & \\
\multirow{2}{*}{ Produced by } & $\begin{array}{l}\text { Department of Information } \\
\text { and Tourism, Taipei City }\end{array}$ & $\begin{array}{l}\text { Department of } \\
\text { Information and Tourism, }\end{array}$ & Information \\
\hline
\end{tabular}




\begin{tabular}{llll}
\hline & Government & Taipei City Government & $\begin{array}{l}\text { Technology, Taipei } \\
\text { City Government }\end{array}$ \\
Key & Hu Xia, Cho Hye Sun & Wu Chung-yen, Ann & Fu Meng-po, Jian \\
characters & & Wei-ling & Man-shu \\
Director & Lo Chien-pin & Hwang He-ching & Lin Chun-chieh \\
Type of film & Romance & Romance & Romance \\
\hline
\end{tabular}

\section{Comparative Analysis of Film Texts}

The three micro films were, based on the space, landscapes, cultural connotation, and lifestyles presented, analyzed in terms of their respective plot, characters, dialogs, landscape, and scenery presented in order to better understand how Taipei city is being depicted in these films.

4.1 Plot

Table 2. Plots of the Three Micro Films

\begin{tabular}{|c|c|c|c|}
\hline & Love@Taipei & My Micro Tour of Taipei & Happily Ever After \\
\hline Opening & $\begin{array}{l}\text { Male lead, who has } \\
\text { traveled from } \\
\text { Beijing, meets } \\
\text { female lead from } \\
\text { South Korea in } \\
\text { Taipei }\end{array}$ & $\begin{array}{l}\text { Male and female leads } \\
\text { meet by chance in Taipei }\end{array}$ & $\begin{array}{l}\text { Male and female leads } \\
\text { agree to meet at six in } \\
\text { the evening }\end{array}$ \\
\hline $\begin{array}{l}\text { Intermediate } \\
\text { part of the } \\
\text { narrative }\end{array}$ & $\begin{array}{l}\text { Male and female } \\
\text { leads tour various } \\
\text { Taipei landmarks } \\
\text { together }\end{array}$ & $\begin{array}{l}\text { Male and female leads } \\
\text { tour various Taipei } \\
\text { landmarks together, and } \\
\text { they end up dating }\end{array}$ & $\begin{array}{l}\text { Female lead is } \\
\text { suspicious of male } \\
\text { lead, decides to follow } \\
\text { him }\end{array}$ \\
\hline Ending & $\begin{array}{l}\text { Male and female } \\
\text { leads end their } \\
\text { respective trips with } \\
\text { complicated } \\
\text { feelings }\end{array}$ & $\begin{array}{l}\text { Male and female leads } \\
\text { go off to pursue their } \\
\text { respective dreams }\end{array}$ & $\begin{array}{l}\text { Male lead proposes to } \\
\text { female lead with a } \\
\text { bouquet of flowers } \\
\text { and a ring to the } \\
\text { female lead's surprise }\end{array}$ \\
\hline Narrative structure & $\begin{array}{l}\text { Straightforward, } \\
\text { easily understood }\end{array}$ & $\begin{array}{l}\text { Straightforward, easily } \\
\text { understood }\end{array}$ & $\begin{array}{l}\text { Straightforward, } \\
\text { easily understood }\end{array}$ \\
\hline $\begin{array}{l}\text { Narrative method } \\
\text { Film themes }\end{array}$ & $\begin{array}{l}\text { Linear narrative } \\
\text { Unclear }\end{array}$ & $\begin{array}{l}\text { Linear narrative } \\
\text { Different captions in } \\
\text { various episodes }\end{array}$ & $\begin{array}{l}\text { Linear narrative } \\
\text { Smart City Blissful } \\
\text { Taipei }\end{array}$ \\
\hline
\end{tabular}


Subject to the duration characteristic of the micro film format, both Love@Taipei and My Micro Tour of Taipei consist of multiple episodes of no longer than five minutes each, while Happily Ever After was also released in an edited three-minute version even more suitable for viewing on mobile devices. In line with traditional film narrative structures, all three micro films use the linear narrative with an emphasis on the linear principle of a single time dimension and on the cause and effect logic. This includes the completeness of the narrative structure (opening, development, climax, and conclusion) and the continuity of space-time unification. In Love@Taipei and My Micro Tour of Taipei, we see events unfold within a certain period, while in Happily Ever After, the narrative takes place over a single day. However, the narrative structure of all three micro films is straightforward and easily understood, meaning that the viewer would be able to grasp the narrative trajectory fairly quickly.

Although all three micro films have taken romance as the main theme, Love@Taipei and My Micro Tour of Taipei share a more similar narrative structure: the male and female leads meet for the first time in Taipei, and they then experience the sights and characteristics of the city together. In both micro films, although the male and female leads part ways at the end, they leave Taipei with spiritual satisfaction and healing, as well as happy memories and emotions when pursuing their respective dreams. This implies that Taipei city is a city where one can recharge one's energies for the next phase in life. In Happily Ever After, the modernization of Taipei and the convenient life it offers are portrayed through the narrative of the female lead following her boyfriend. Although the story is short and simple, the plot is novel and innovative, with all kinds of new technologies and services cleverly woven into the narrative. The storylines of all three micro films relate closely to the daily lives of Taipei residents, making these films effective examples of Taipei’s local lifestyles and cultures.

Thematic captions and slogans have been used in the three micro films; however, none have been used in Love@Taipei, with only the title of the film flashed across the screen at the end of each episode; in My Micro Tour of Taipei, a different "micro quote" appears in each episode as a summary of the theme in the respective episode. For instance, the theme of the first episode is summarized as "Travel is the [pursuit of] moving of the heart; the most moving moments are actually found in life". On the other hand, a precise slogan "Smart City, Blissful Taipei" is used in Happily Ever After, with the lively narrative and unexpected conclusion of the film both foregrounding the convenient technologies that are in daily use in Taipei as well as the bliss brought on by such conveniences. Here, the theme of the micro film is closely related to the slogan that appears at its conclusion.

\subsection{Characters}


Table 3. Characters of the Three Micro Films

\begin{tabular}{|c|c|c|c|}
\hline & Love@Taipei & My Micro Tour of Taipei & Happily Ever After \\
\hline \multirow{7}{*}{$\begin{array}{l}\text { Key } \\
\text { characters }\end{array}$} & Lead: Hu Xia, singer & Lead: Wu Chung-yen, actor & Lead: Fu Meng-po, actor \\
\hline & Character: a Beijing & Character: Wu Pai-jen, travel & Character: Taipei youth \\
\hline & youth & blogger & Po-chai \\
\hline & Lead: Cho Hye Sun, & Lead: Ann Weiling, actor & Lead: Jian Man-shu, actor \\
\hline & actor & Plays: Ann Hsiao-ching, & Character: a Taipei youth, \\
\hline & Character: an editor & Avid urban explorer & Hsiao-man \\
\hline & from South Korea & & \\
\hline \multirow{4}{*}{$\begin{array}{l}\text { Character } \\
\text { sketches }\end{array}$} & Male lead is bookish & Male lead is calm and & Extroverted and gregarious \\
\hline & and shy, while female & restrained, while female lead & personality \\
\hline & lead has a sensitive and & has an extroverted and lively & \\
\hline & sweet personality & personality & \\
\hline \multirow{2}{*}{$\begin{array}{l}\text { Other } \\
\text { characters }\end{array}$} & Cabby, busker, etc. & Café owner, friend of female & Friends of the male and \\
\hline & & lead, etc. & $\begin{array}{l}\text { female leads, convenience } \\
\text { store worker, etc. }\end{array}$ \\
\hline
\end{tabular}

Regarding the duration and production characteristics of the micro film, it is best that the character sketches for such films remain simple. This is the case for all three micro films under study: all three narratives center on a male lead and a female lead, with few supporting characters and clearly defined interpersonal relationships. In all three micro films, the male and female leads are either dating or possibly attracted to each other. The narrative takes place over a longer period in Love@Taipei and My Micro Tour of Taipei, with the viewer learning how the male and female leads meet for the first time as well as how they develop affection for each other. Here, the screen time for both the male and female leads is approximately equal. On the other hand, in Happily Ever After, the narrative begins with the male and female leads already dating each other and ends with the relationship between the two brought to a whole new level. However, the female lead dominates screen time here.

Although the key theme for all three micro films is romance, the personalities and attributes of the respective leads differ as a result of the differences in storylines. The male and female leads of Love@Taipei are visitors from Beijing and South Korea respectively, and images of Taipei’s vitality and other characteristics are depicted through the perspective of these visitors or "outsiders". Both $M y$ Micro Tour of Taipei and Happily Ever After feature local characters in the lead roles. [In the former], the male lead is calm and restrained, while the female lead has an open and lively personality. Particularly in Happily Ever After, the extroverted, gregarious, and slightly tomboyish personality of the female lead comes through in her actions, dress, and tone. The characters [of the latter two] 
correspond with the city image of Taipei as shown in these films: youthful and vibrant.

The shaping of Taipei's city image can also be discerned from the choice of actors for all three micro films: the leads are played by young actors in what is a display of the city's youthful and vibrant side. All three micro films feature artists of some reputation. Of the three, only Love@Taipei features a mainland Chinese singer and a South Korean actor as part of its strategy to create a stronger impact and attract more visitors from these two countries. The actors featured in My Micro Tour of Taipei and Happily Ever After are popular with younger audiences for their fresh and natural images. The popularity and reputation of these actors can also create an even stronger promotional effect for these films.

\subsection{Dialogs}

Table 4. Dialogs of the Three Micro Films

\begin{tabular}{llll}
\hline & Love@Taipei & My Micro Tour of Taipei & Happily Ever After \\
\hline $\begin{array}{l}\text { Dialog/voiceover } \\
\text { characteristics }\end{array}$ & Internal narratives, & Literary-styled records & Daily conversations, \\
& diary-style confessions & & brief conversations \\
\hline
\end{tabular}

The dialogs and voice-overs in the films present the linguistic characteristics of the city through accents, diction, and syntax. In Love@Taipei, the foreign accents of male and female leads give the film an exotic touch, with the liberal use of diary-style confessions by both leads containing both snippets of their emotions and their feelings about Taipei. The interactions between the male lead and the taxi driver and between the female lead and passers-by also serve to showcase the friendliness and kind disposition of the city's residents. In My Micro Tour of Taipei, the literary-styled records of both the male and female leads work to present Taipei as a city of artistic inclinations and romance. However, in Happily Ever After, the briefer dialogs are what one could expect to hear in everyday life. The content, diction, tone, and accents used in these dialogs are all very compact and can fully reflect the language culture prevalent among young Taipei residents today. For instance, phrases such as hao la (alright) and daodi zai gao shenme la (what exactly are you up to) are commonly used and heard in real life. In all three micro films, the landmarks and amenities of Taipei city are introduced in text form, allowing audiences [unfamiliar with the city] to develop their impressions of Taipei through audio and visual cues and to reinforce their impressions via visual texts.

Diegetic music used in all three films is also notably diverse, ranging from light and brisk pieces to suspenseful jazz pieces and gentler interludes. These pieces, which are in accord with changes in the leads' moods, plot development, and changes in plot rhythm, make for more animated films that draw audiences into their respective fictional worlds even more deeply. Moreover, these films are rich in diegetic sounds such as the sounds of traffic, of doors opening in convenience stores, of Metro trains, of busking, and of passers-by. The inclusion of these sounds serves as a reflection of life in Taipei. 


\subsection{Landscape and Scenery}

The visual presentation of [Taipei's] landscape and scenery is the most direct way of creating city image. Here, we divide landscape and scenery into two categories: the material and the non-material. The former includes elements such as buildings, food and drink, and everyday icons, while the latter includes [less tangible] elements such as lifestyle, values, and ideologies. The following table shows the type of symbol appearing in the three micro films under study:

\section{Table 5. Landscape and Scenery of the Three Micro Films}

\begin{tabular}{|c|c|c|c|c|}
\hline \multicolumn{2}{|c|}{ Symbol Type } & \multirow{2}{*}{$\begin{array}{l}\text { Love@Taipei } \\
\text { TAIPEI 101, the LOVE sculpture }\end{array}$} & \multirow{2}{*}{$\begin{array}{l}\text { My Micro Tour of Taipei } \\
\text { Taipei Public Library Beitou Branch, }\end{array}$} & \multirow{2}{*}{$\begin{array}{l}\text { Happily Ever After } \\
\text { The Taipei Expo Park }\end{array}$} \\
\hline & Buildings & & & \\
\hline & & & TAIPEI 101, the LOVE sculpture, heritage & \\
\hline & & & sites with Japanese style architecture & \\
\hline Images of & Traffic intersections, & Zhongxiao East Road, taxis, buses, Metro, the & The streets of Taipei, bus stops, Metro & Taipei Metro, the streets of Taipei, \\
\hline the & landmarks & streets of Taipei, Songshan Airport, Ximending, & stations, Songshan Cultural and Creative & bus stops, U-bike rental stops \\
\hline \multirow[t]{20}{*}{ material } & & Songshan Cultural and Creative Park & Park, Dadaocheng Wharf, Taipei Circle, & \\
\hline & & & The Ferris Wheel at Miramar Park, & \\
\hline & & & Maokong gondola/tea plantation, & \\
\hline & & & Liugongjun sites, Longshan Temple, & \\
\hline & & & Riverside Park, Yangmingshan National & \\
\hline & & & Park & \\
\hline & Landmarks of & Café, park & Café, park & Convenience store, café \\
\hline & day-to-day life & & & \\
\hline & Food & Various snacks, Western-style desserts, mala & Hot spring eggs, various snacks, mala & \\
\hline & & hotpot & hotpot & \\
\hline & Entertainment and & Baseball, Eslite bookstore, Shilin night market, & Baseball, Shilin night market, Taipei at & \\
\hline & leisure & Night scenes of Taipei, Xinsheng basketball & night, Gongguan Business District, East & \\
\hline & & court, Yongle market, creative exhibitions, & District Business Circle, Xinyi Business & \\
\hline & & Xinyi Commercial Center, playgrounds, Ximen & District, creative industry merchandise & \\
\hline & & Red House Creative Bazaar & & \\
\hline & New technologies/ & & Youth-oriented loans, mobile handset & Love@Taipei Cloud Municipal \\
\hline & services & & charging services at Metro stations & Affairs Service, parking payment \\
\hline & & & & SMS alert service, Multimedia \\
\hline & & & & Kiosk services at smart convenience \\
\hline & & & & stores, package pickup services at \\
\hline Images of & & & & convenience stores, 1999 Citizen \\
\hline the non- & & & & Household Affairs Hotline, the \\
\hline
\end{tabular}


Scenes of Taipei have been cleverly inserted into all three micro films to express in ways that undergird the respective themes. In Love@Taipei and My Micro Tour of Taipei, the male and female leads visit several city sights—which serve as rich material symbols for city image-as their relationships progress. In addition, certain sights appear more than once in both films, and hence, they are regarded as representative of the city. These include the symbol of modernity-TAIPEI 101, the convenient Metro system and other transport facilities, and the distinctly local food and beverage options, almost running the gamut of symbol images associated with life in Taipei. It is worth noting that in these two micro films, we see signs of the up-and-coming creative industry. Not only do we see images of Taipei’s Creative Parks but also various merchandises created by the industry players. Such inclusions serve to highlight the innovative side of Taipei. In Happily Ever After, which focuses on Taipei as a smart city, various science and technology services and amenities described in the table above are woven into the narrative by having the male and female leads use these facilities as the story unfolds. This allows the viewer to appreciate the benefits of such facilities and science and new technology in day-to-day life in Taipei, including convenience, accessibility, and a close relation to the needs of residents. This micro film portrays life in Taipei in a realistic, everyday light, with multiple sources of information in the film content portraying a picture of a smart city that is modern, technologically advanced, and offers a plethora of conveniences. Furthermore, not only does the film serve to enhance Taipei's city image, [the presentation of how] but the used facilities effectively frame the Taipei city government, as the planner and implementer of relevant policies, in a positive and progressive manner. The landscapes and scenery shown in these three micro films also convey non-material images of the city. In Love@Taipei, the city is one that is warm, free, and full of goodwill among men; the writing of the male lead in My Micro Tour of Taipei speaks of a city that is full of artistic inclinations and one where individuals can discover their dreams and life goals; in Happily Ever After, the use of various municipal services brings out the idea of a city that is technologically advanced, modern, and offers plenty of conveniences.

Besides the above analysis of the plots, characters, dialogs, as well as landscapes and scenery, the distinctive features of micro films [produced to market] in Taipei are also noted. First, all three films are centered on the theme of romance, which enjoys wide popularity and offers significant room for Published by SCHOLINK INC. 
plot developments. Further, the theme of romance is one that the target audience of these films, particularly younger viewers, can readily identify with.

Second, the design of certain color palettes across the three micro films also serves to accentuate various city images. The logos and backdrops in these films are presented in pastel tones or bright colors, and designs used are lively, bright, and highly stylish. These blend together with the various characters and plot development and underline the youthful and vibrant aspect of Taipei's city image. In Happily Ever After, the services and amenities shown are replayed at the end of the film as a means of reinforcing the viewer's impression of these facilities.

Third, although all three micro films have been produced to promote Taipei, Love@Taipei and My Micro Tour of Taipei, with their comprehensive coverage of transport, food, and entertainment in the city are inclined toward tourists from overseas. While on one hand, Happily Ever After works to showcase the modern aspects of Taipei for foreign tourists, the micro film is, on the other hand, a display of municipal policy outcomes for the city's residents that would [hopefully] inspire a sense of happiness about living in the city as well as strengthen the support for the city government.

Fourth, although the three micro films were produced at the behest of various government agencies, there are very few indicators in the content of these films of such origins. For example, the tag lines “Smart City, Blissful Taipei” in Happily Ever After and “Taipei, One Visit Isn’t Enough!” in My Micro Tour of Taipei appear only at the end of the films together with the name of the commissioning unit. As such, the entertainment value of these films is enhanced as the role of the commissioning government agencies is relegated to the periphery [of the presentation].

\section{Conclusion and Recommendations}

In recent years, with the swift development of the media, an increasing number of corporations and even government agencies are using the new format known as the micro film as a means of advertising and marketing. In this study, three micro films produced by the Taipei City government were studied. It was found that in these films, the [appropriate selection of] celebrity performers, the romance narratives used, and the lively presentation have created attractive film content that presents an image of Taipei that is free, friendly, diverse and progressive. Further, these films have also successfully conveyed the message that "Taipei is a city that is energetic, positive, and full of potential". These films have been made with great skill and depict little traces of the government-run campaigns they are actually part of, making them even more entertaining for viewers.

Follow-up studies can focus on either quantitative studies of the relevant literatures or qualitative audience studies to seek a better understanding of the kinds of knowledge, attitudes, and behavioral intentions presented in city micro films of various stripes as well as to examine how the viewer interprets film content in the course of watching such films. Such studies would help government agencies to create even better examples of such films in the future. 


\section{References}

Ashworth, G. J., \& Voogd, H. (1990). Selling the City. England: Wiley.

Beeton, S. (2005). Film-induced tourism. Clevedon: Channel View Publications.

Chen, L.-M. (2008). Preliminary Explorations into the Narrative Structures of German Modernist Novels. Contemporary Foreign Literature, 2, 38.

Chen, X.-W. (2014). Creating Meaning in the Micro Film. Contemporary Cinema, 5, 98-102.

Chen, Y.-C. (2012). An Analysis of the Development and Business Model of the Micro Film (online resource). Market Intelligence \& Consulting Institute. Retrieved from http://mic.iii.org.tw/aisp/ reports/reportdetail_register.asp?docid=2998\&rtype=freereport

Connell, J., \& Meyer, D. (2009). Balamory revisited: An evaluation of the screen tourism destination-tourist nexus. Tourism Management, 30, 194-207.

Graham, B. (2002). Heritage as Knowledge: Capital or Culture? Urban Studies, 39,1003-1017.

Hwang, C.-C. (2013). Comparing the Impact of Micro Film Advertising, Advertising Through Episodic Narratives and Advertising Through Serialized Narratives: The example of the Hakka Affairs Council. Advertising Yearbook of Taiwan, The Republic of China 2012-2013. Taipei: Taipei Association of Advertising Agencies, 24, 41-48.

Kotler, P. (2002). Marketing Asian Places: Attracting Investment, Industry, and Tourism to Cities, States and Nations. Taipei: Shang-chi Culture.

Lee, C.-Y. (2011). A Study of Film and City Marketing: The example of Taipei (Master's Thesis). School of Communication, Ming Chuan University, Taiwan.

Lin, W.-J. (2009). A Study of Evaluation Indicators Used for the Building of the City Brand through Large-Scale Events (Master's Thesis). Department of Advertising, National Chengchi University, Taiwan.

Wu, P.-T. (2007). In the Age of Filmic Thinking. Taipei: Bookman.

Yahoo! Kimo. (2002). Creative Thinking on Promotion and Marketing: When city marketing meets the micro film (online resource). Retrieved from https://marketing.tw.campaign.yahoo.net/ emarketing/main/A01/B02?id=576 